\title{
ArcheoSciences
}

Revue d'archéométrie

33 (suppl.) | 2009

Mémoire du sol, espace des hommes

\section{Magnetic prospection of Scythian Kurgans from Chilik, Southeastern Kazakhstan}

Jörg W. E. Fassbinder, Tomasz Gorka, Hermann Parzinger and Anatoli Nagler

\section{(2) OpenEdition}

12 Journals

Electronic version

URL: https://journals.openedition.org/archeosciences/1284

DOI: 10.4000/archeosciences. 1284

ISBN: 978-2-7535-1599-4

ISSN: $2104-3728$

Publisher

Presses universitaires de Rennes

Printed version

Date of publication: 30 October 2009

Number of pages: $59-61$

ISBN: 978-2-7535-0943-6

ISSN: 1960-1360

\section{Electronic reference}

Jörg W. E. Fassbinder, Tomasz Gorka, Hermann Parzinger and Anatoli Nagler, "Magnetic prospection of Scythian Kurgans from Chilik, Southeastern Kazakhstan", ArcheoSciences [Online], 33 (suppl.) | 2009, Online since 30 October 2011, connection on 01 February 2022. URL: http://journals.openedition.org/ archeosciences/1284; DOI: https://doi.org/10.4000/archeosciences.1284 


\title{
Magnetic prospection of Scythian Kurgans from Chilik, Southeastern Kazakhstan
}

\author{
Jorg W. E. Fassbinder*, Tomasz Gorka*, \\ Hermann PARZInger ${ }^{* *}$ and Anatoli Nagler ${ }^{* * *}$
}

Key words: Magnetic prospection, Scythian period, Burial mound, Kurgan, Kazakhstan.

\section{INTRODUCTION}

The Scythians and the Sarmatians were nomadic horseriding-people who populated the Eurasian steppe from south Siberia and Kazakhstan through Caucasus up to Hungary. The horses were the power basis of the Scythian peoples. As nomadic pastoralists they dominated the Pontic steppe throughout Classical Antiquity from 1000 to 400 BC. In the past it was asserted that they have left no remnants or traces of settlements, but this has now been challenged (Becker \& Fassbinder, 1999; Schneeweiß, 2007). The most outstanding monuments of the pastoral nomadic sites in the steppe are the huge burial mounds, the so called kurgans. They were not only the burial plots of the kings, but were used by the horsemen as cultic and sacred places as well (Parzinger, 2004).

\section{ArChaEOlogical baCKGround}

Semiretschje in southeastern Kazakhstan, named after the land of seven rivers - Ili, Karatal, Bien, Aksu, Lepsy, Baskan and Sarkand, is a central region in the Eurasian steppe belt. In this area, 10000 burial mounds can be found, but also hundreds of monumental and huge kurgans of 10-20 m height. The prominence of this region draws from the large and fertile lowlands which are ideal for cattle-breeding and from the abundance of gold, tin and copper in the mountains. The kurgans, dating to $500 \mathrm{BC}$, do not occur as single monuments but are mostly lined up in rows. It is a widely accepted that the higher the kurgan, the more important the person buried in it. This pomposity is typical of the early horse-riding people from the 5 th to the 3 rd century BC. The wealth buried inside the kurgans have made them a tempting target for looters ever since ancient times.

A row of kurgans is situated c. $120 \mathrm{~km}$ east of Almaty and $12 \mathrm{~km}$ northeast of the town of Chilik. The flat area which is bordered on the north and south by mountain ranges is not far from the northern route of the Silk Road. The area between these mountains was a suitable grazing land for the horse people and nomads, but could have also been used for agriculture since the early periods of settlement.

The huge barrow "Zhuan-Tobe" is c. $12 \mathrm{~m}$ high, $107 \mathrm{~m}$ in diameter and was made of several layers of clay and gravel. It is about 2500 years old and was looted more than 100 years ago. The kurgan forms the biggest burial of a row of barrows oriented north-south. The second array of smaller kurgans lies at a distance of $600 \mathrm{~m}$. The mounds seem to be part of the same necropolis.

\footnotetext{
* Bavarian State Department. of Monuments and Sites, Hofgraben 4, 80539 Munchen, Germany. (joerg.fassbinder@blfd.bayern.de)

** Stiftung Preußischer Kultubesitz, Von-der-Heydt-Str.16-18, 10785 Berlin,Germany, (parzinger@hv.spk-berlin.de)

*** Deutsches Archäologisches Institut, Eurasien-Abteilung, Im Dol, 2-6, 14195 Berlin, Germany. (an@dainst.de)
} 


\section{ResEARCH QUeSTION}

Research questions are manifold. Assuming that the burial sites form a sacred place, it would be interesting to find out whether they formed a linked system or stood alone? Stone plaster remains visible in a field $40 \mathrm{~m}$ from the biggest kurgan and several smaller stone burials found in the area in between could be related to the big kurgan, but they could well belong to a later archaeological period. The smaller burials have been observed to have different layouts, some being round and others square. In every row of kurgans there is one with a quadratic or pyramidal foundation. Consequently, it is of great interest to carry out a large-scale survey also of the peripheries of the kurgans (Fassbinder \& Becker, 2003).

\section{Magnetic prospection}

For magnetic surveying the Scintrex Smartmag SM 4GSpecial caesium magnetometer in the so called duo-sensor configuration was chosen. Diurnal variations were reduced to the mean value of all data from the $40 \times 40 \mathrm{~m}$ grid. Sometimes this configuration is disadvantageous, because the results are strongly affected by the geological background. However in the case of the high kurgans and deep burials, it was actually thought to be helpful to get some additional information from the deeper section. Due to access and time restrictions, the prospection work was focused on the largest kurgan called Zhuan-Tobe 1 and its surroundings, as well as three smaller barrows in the second row.

The resulting magnetogram of the great kurgan reveals the perfect circle of the burial mound ( $107 \mathrm{~m}$ in diameter), surrounded by a $2 \mathrm{~m}$-wide outer ring with an outer diameter of $187 \mathrm{~m}$ (Fig.1). Traces of looting in the centre of the mound show up as a typical cone-shaped form. The magnetogram of the mound reveals no traces of an inner structure, which should be taken to mean that the entire burial was made of homogeneous layers of clay and gravels. Between the mound and the outer ring a number of other burials, some of them round and others rectangular, were detected. The magnetic map reveals that the orientation of these small burials in relation to the great kurgan is more or less erratic, indicating that they originate from a later archaeological period. The resulting magnetogram of the smaller but pyramidal-shaped kurgan (c. $4 \mathrm{~m}$ in height) reveals traces of looting, but also some evidence of an inner square structure (Fig. 2).

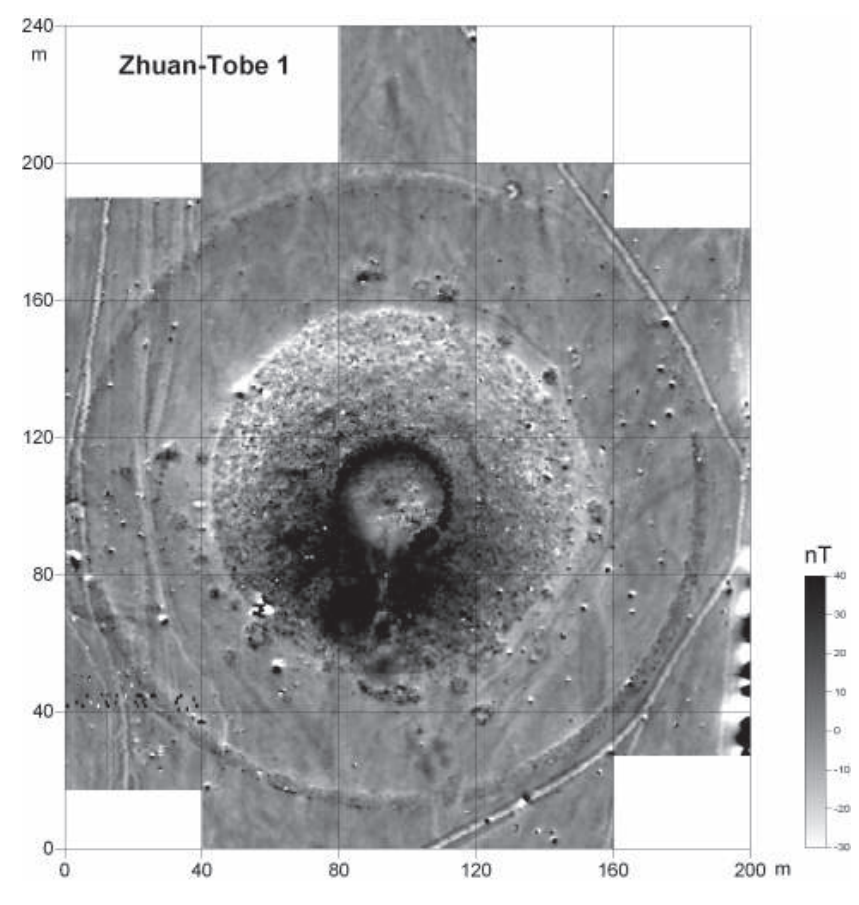

Figure 1: Magnetogram of the great kurgan Zhuan-Tobe 1 near Chilik and its surroundings (top of the site points north).

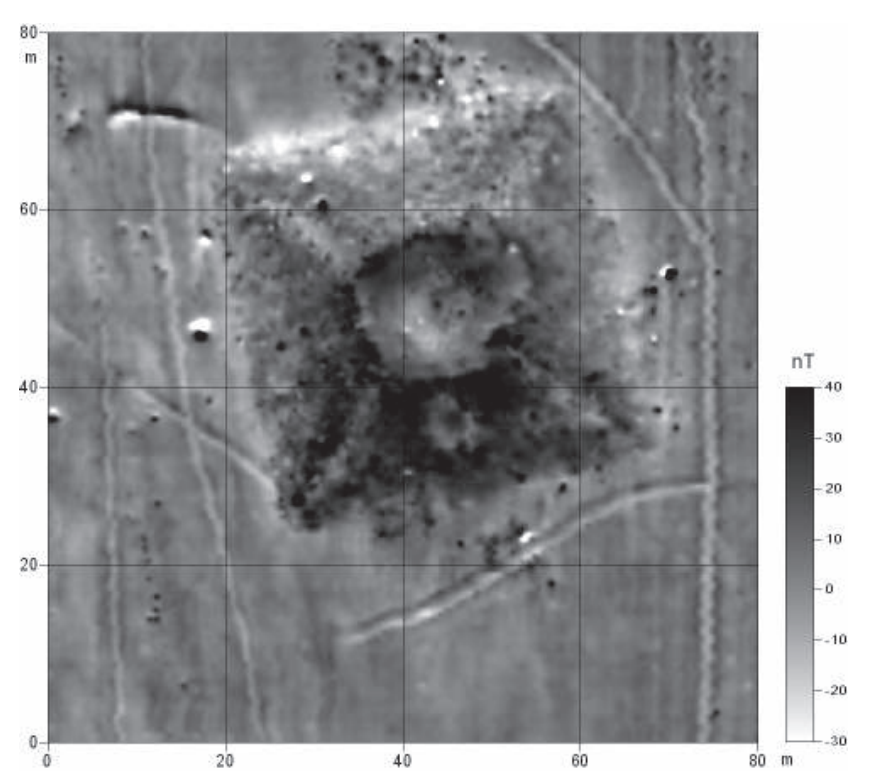

Figure 2: Magnetogram of a square-shaped kurgan and its surroundings, c. $600 \mathrm{~m}$ away from Zhuan Tobe 1 near Chilik, Kazakhstan (top of the site points north). 


\section{ConCLusion}

The magnetic prospecting resulted in detailed maps of these large archaeological sites. Although it is not possible to look into the deeper parts of a kurgan, crucial information has been delivered on the structure of the upper part of the burial and a site map of the surrounding area has been obtained. The small burials around the kurgans are not related to the Scythian/Sarmatian times, but they demonstrate beyond all doubt that the kurgans were sacred places that attracted people for burial purposes also in later archaeological periods.

\section{References}

BeCKer, H. and Fassbinder, J. W. E., 1999. Magnetometry of a Scythian settlement near Cica in the Baraba Steppe. In Fassbinder, J. W. E., Irlinger, W. E. (dir.). Archaeological Prospection, Arbeitsh. Bayer. Landesamt f. Denkmalpflege 108, München, 168-172.

Fassbinder, J. W. E. and Becker, H., 2003. Magnetometerprospektion des großen Kurgans 1 von Bajkara. Arch. Eurasien, 16: 131-136.

Parzinger, H., 2004. Die Skythen. C.H.Beck München

Schneeweiß, J., 2007. Die Siedlung Cica in der westsibirischen Waldsteppe. Arch. Eurasia, 22: 1-422. 